\title{
Discussion on college students' ideological and political education in the we-media era

\author{
Hailong SHAO ${ }^{1, a}$, Dongju DU ${ }^{2, b}$
}

${ }^{1}$ College of Engineering and Technology, Jilin Agricultural University, Changchun, 130118, China

${ }^{2}$ College of Animal Science and Technology, Jilin Agricultural University, Changchun, 130118, China

aemail: shaohailong1992@126.com, bemail:473352805@qq.com

Keywords: college students; ideological and political education: Internet+; innovation

\begin{abstract}
We-media is an important symbol of the advent of the individual media era. Especially with the development of network techniques, new media represented by WeChat and microblog have diversified communication platforms for we-media. College ideological and political educators no long have information advantages, who are even stuck into an embarrassed situation of group aphasia. This is a great dilemma brought by the we-media era to college students' ideological and political education and a new challenge against ideological and political educators ${ }^{[1]}$. To correctly realize the application value of we-media, vigorously carry forward the positive energy of moral education under the we-media environment and actively get adapted to the "Internet + " era-these have been the new normal of ideological educators.
\end{abstract}

\section{Introduction}

Explosive development of we-media techniques have driven people into the we-media era. Social networks, including microblog, Renren.com and Kaixin001.com, have become overnight sensations in campuses and society. The concept that "I am the media" has been around. The era background has posed unprecedented challenges to college students' ideological and political education.

\section{Characteristics of we-media}

Popularization and massification

The first characteristic of we-media is popularization and massification. We-media is simple to operate, which calls for no specialized technical knowledge or any input cost. This lowers the threshold of we-media, and is in line with the complex and low-cost lifestyle.

\section{Independence}

In terms of use characteristics, we-media is independent. Everyone can have their own "network newspaper" or "network broadcasting." It seems media has become a household belonging. People can speak out freely on their own media, freely air their opinions and ideas, and share their happiness and sorrow. All in all, we-media has been the best place for college students to be their true self. It is in line with college students' yearning for speech freedom.

Instantaneity and interactivity

We-media is instantaneous and interactive, whose communication is free of limits of space and time. It can be operated at any time. Audiences can quickly respond to, comment and forward information. Instantaneity and interactivity of we-media is closely in line with college students' fast pace of life and their eagerness to get attention.

Diversification

In terms of information source, we-media is diversified, which meets university students' 
desire of achieving diversified development and learning different information. The generation and characteristics of we-media coincide with college students' age characteristics, lifestyle and psychological state. With growing popularity, it has formed an extensive influence among college students $^{[2]}$. Its appearance is a response to the current information development trend and the product of the era.

\section{Role of we-media in colleges' ideological and political education}

Microblog, WeChat and other we-media platforms have been deeply-rooted among college students. This is an indisputable fact. To do a good job in college students' ideological and political education relies on the role of we-media. We-media has been integrated into life and learning of college students, exerting a subtle influence on college students' ideas and behaviors. Colleges' ideological and political education cannot be separated from participation of the we-media platform. It is all the more necessary for ideological and political educators in colleges to study the application value of we-media in ideological and political education.

\section{Establishment of a new working platform}

Along with the emergence of we-media represented by WeChat and microblog, ideological and political educators in colleges are faced with increasing challenges, such as challenges of main ideas and practices. On the other hand, we-media, based on its unique communication styles and influencing styles, has created new platforms for college ideological and political educators to learn students' ideological changes. For example, we-media communication is fast and extensive. College ideological and political educators can make full use of this, master students' psychological state immediately, and learn their ideological problems. At the same time, we-media can help increase ideological and political educators improve their working efficiency, immediately and correctly convey their and school's requirements to students, and enhance their connection with students.

\section{Full stimulation of educators' learning initiative}

By fully displaying mobile Internet operation skills of the post-95s, we-media can hopefully change the one-way output situation of the traditional moral education, change the passive traditional educational mode and efficiently give full play to college students' subjective initiative. In this way, students and teachers can communicate with each other on equal terms and the efficiency of moral education can be maximized. This also highlights advantages of we-media, which is highly opening and interactive. The anonymous tool characteristic of we-media can guide college students pour out their feelings and save their worry of face-to-face communication. Teachers and students can talk with each other heart-to-heart. We-media has enriched information source channels for educators to college students' ideological status. With a good understanding of what college students think, ideological and political educators can talk with students more naturally, which can contribute to efficiency of college moral education. While giving full play to independence of we-media, educators should actively lead students to form a moral consciousness of self-discipline and prudence, requiring students to strictly act with the Internet's "seven bottom lines," consciously abide by civilized pledge on the Internet and reasonably express ideas. Moral educators should also teach students to tell right from wrong and increase their ability to screen information.

\section{Strengthening of the relationship between students and teachers}

Various information platforms of we-media can immediately and correctly express students' eagerness to learn the status of their school. Through the friend circle, QQ zone and other network platforms, schools can provide students with information about daily learning, part-time work and climate. In this way, administration personnel can close their relationship with students, or even become friends. They can put themselves into each other's shoes, and actively interact with each other. On the one hand, this is conducive to forming a harmonious interpersonal relationship in colleges; on the other hand, this can guide students' ideological status. 


\section{Establishment of "associations”}

Associations in colleges are built by a group of students with the same interests. Because of their shared interests, they are willing to input more time and energy. As the saying goes, "interest is the best teacher.'To reasonably use resources of associations and to enhance the we-media platform construction of associations are of vital importance to colleges' political work. In order to enhance political education, some associations related to China's revolutions and politics can be set up, such as the Anti-Japanese War Theory Research Institute, Socialist Theory with Chinese Characteristics Research Institute and Three Representatives'Theory Discussion Group. More support should be given to these organizations and associations so that students can relate these organizations and associations more with their life and learning. Besides, through we-media platforms, we-media platforms can influence students’ ideological concepts unwittingly.

\section{Building of themed educational platforms}

College ideological and political educators can make use of we-media to build a brand-new BBS or classroom. On the online classroom, the Marxist themed education can be conducted to equip contemporary college students with Marxist ideas, show to them the greatness of Marxist ideas and lead them to apply them to daily life and learning, thus increasing their own cultivation. On the BBS, topic discussion can be held. Students can exchange ideas with each other. In this way, ideological and political education is integrated into every classmate's life, avoiding limits of distance and location and increasing classmates' degree of participation. Besides, on the network platforms, teachers and students can discuss with each other, solving problems related to their learning and life ${ }^{[3]}$.

\section{Establishment of the role model platform}

In institutions of higher learning, role models are indispensable. Positive role models can stimulate students' learning enthusiasm. Negative role models might lead them to go on the wrong track. The emergence of we-media platforms has enabled college ideological and political workers to create role model platforms to publicize positive role model, who can lead other students ideologically $^{[4]}$. All in all, the we-media trend is irresistible. Under the we-media environment, how to adopt novel and practical methods to realize innovation of college students'ideological and political education calls for unremitting exploration of ideological and political educators.

\section{Conclusions}

To sum up, in the face of the irresistible trend of we-media, college moral educators should make scientific use of we-media, scientifically seize opportunities and challenges brought it, skillfully use it to increase efficiency of college moral education, avoid its hazards and adopt its strengths to promote coordinated innovation and development of we-media and college moral education.

\section{References}

[1] JIAO Hongqiang. Enlightenments of "micro-era” for ideological and political education in institutions of higher learning[J]. Henan Education, 2012 (6).

[2] TANG Lifeng \& WANG Xuechuan. Innovation of college ideological and political work under the we-media environment[J]. China Youth Study, 2012 (3).

[3] DU Wenli. We-media microblog and college students' ideological and political education[J]. Shenzhou, 2011 (4).

[4] JIN Yongsen. Innovation of college students' ideological and political education under the microblog environment[J]. Journal of Fujian Commercial College, 2011 (3). 